\title{
GSSP, IUGS and IGC: an endless story toward a common language in the Earth sciences
}

\author{
Dip. STGA, Via Zamboni 67, I-40127 Bologna, Italy. E-mail: vai@ geomin.unibo.it
}

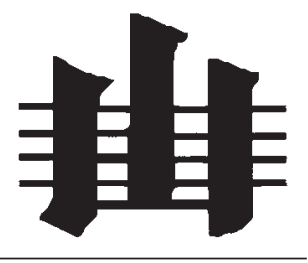

\begin{abstract}
Less than one third of Phanerozoic chronostratigraphic units has been formally defined in the last thirty years. Two thirds are still floating. A common relative chronologic language is crucial to modern communication among the different disciplines stemming from the old geoscience root and with the neighboring physical, chemical, natural and environmental sciences. To strengthen the perspectives of geosciences in the near future and test the capacity of geologists to succeed in co-operative scientific goals, every effort should be made to complete definition of the chronostratigraphic scale within the next decade.
\end{abstract}

\section{Introduction}

About thirty out of a total of about 100-130 stages (and related series and systems), recognized worldwide to form the Phanerozoic part of the Geological Time Scale, have been formally defined so far. Earth scientists, for whom the use of time units is crucial, can refer to these stages in a unique, uniform, and standardized manner worldwide, being assured that such names have maintained and will keep the same meaning even in the future.

However, what about the remaining $2 / 3$ of stages still waiting for formal definition? A long time was necessary to define the first thirty stages, and the large number of stages still not defined implies that the struggle for a unified chronological terminology is far from being over.

This is an attempt to review the state of the art in view of the 31 st IGC in Rio de Janeiro 2000, about two centuries since the foundation of stratigraphy was set and 119 years after the definition of the chronostratigraphic unit concept accepted at the 2nd IGC in Bologna 1881 .

\section{Old stratigraphic approach}

For almost seven decades (until the 50s of 20th century), geologists were satisfied with the chronostratigraphic units as tools for common rock-time subdivision (Stratigraphic Scale) based on unit-stratotypes characterized by diagnostic fossils (assemblages separated by biotic breaks and stratal unconformities) and correlated through them whenever and wherever possible.

Advancements in the fields of petroleum geology, which made use of the related biological-physical-chemical correlation tools, resulted in a sharp increase of stratigraphic resolution power. This, in turn, allowed the recognition of (i) overlap or gap between unit-stratotypes, (ii) miscorrelation among regional stratotypes, and (iii) lack of unequivocal temporal meaning of many chronostratigraphic units.

\section{New stratigraphic approach}

The time was ripe for updating and improving the stratigraphic principles and practice with the aim to develop a worldwide scale of chronostratigraphic units (Global Standard Stratigraphic Scale), representing the continuity of geologic time as implied in the chronologic units. This goal could have been achieved, if stratigraphers would have looked for boundary-stratotypes in appropriate continuous marine sections of uniform facies correlative to traditional boundaries between chronostratigraphic units, which were usually placed at unconformities. This approach respected the tradition and the previous consolidated usage of names and scales. It aimed at producing the least possible alteration in nomenclature and language. It provided, however, a much more precise and univocal common language in chronological geology. Soon it was clear that this process of precise definition or redefinition of boundaries could have implied amendment of the chronostratigraphic range and chronologic duration of some units and, therefore, changes at the local or global level.

Such a new stratigraphic philosophy was first applied in an official document during the 18th IGC London 1948 to introduce the recommendations to the Italian Geological Society to cooperate with the IGC in view of "selecting a type-locality for the precise definition of the Pliocene-Pleistocene boundary" (King, 1950; Oakley, 1950).

\section{Birth of IUGS and ICS}

The birth of IUGS in 1961 was accompanied by the establishment of the ICS as one of the stable bodies within the organization and by the first qualified dissemination of the new stratigraphic philosophy through many sessions of the 21st IGC Copenhagen 1960 (Sorgenfrei, 1964).

The new philosophy soon had to face the problem of the actual definition of the Silurian/Devonian boundary. Integrated pluritaxial worldwide correlation studies in the previous years had shown that the traditional boundary in the British Isles was discontinuous. Besides, the graptolites, the powerful orthochronologic fossil group (Leitfossil) used for dating the chronostratigraphic units of the Ordovician and Silurian systems and thought to be extinct by the Silurian (Monograptus ultimus), was still alive until mid-Devonian time (Erben, 1962). Within ten years, the international ad hoc Committee of ICS-IUGS succeeded in defining, almost unanimously, the first GSSP, showing that the new stratigraphic philosophy and practice was very useful and successful even in cases of unsuitable stratal conditions in the old type area and of global biotic provincialism (Martinsson, 1977). The base of the Devonian became a paradigm in GSSP boundary definition insofar: (i) it moved the type area from the British Isles to continental Europe, (ii) it kept the boundary extremely close to the traditional basal marine Devonian limit, (iii) it used as nominal criterion for selecting the physical plane to be defined as GSSP the first occurrence of a graptolite (Monograptus uniformis uniformis) in the type section at Klonk, near Prague. The latter was an indication to everybody that the boundary-stratotype 
notion instead of the marker-fossil (Leitfossil) notion was followed to choose the base of a chronostratigraphic unit.

It was decided (by the Committee), approved (by the ICS), and ratified (by the IGC-IUGS) that "the boundary should be placed within bed No. 20 in relation to the first occurrence of $M$. u. uniformis". In relation means that the first occurrence of $M$. u. uniformis was used only as the best tool to select the physical surface where to place the "golden spike" (GSSP) of the unit to be defined, at that very moment of the chronostratigraphic definition procedure. Once the GSSP was defined, it would not change anymore. One could later change the tool, but not the physical boundary, even if $M$. u. uniformis would prove to appear earlier or later in the Klonk section or anywhere in the world. A better correlation tool would have been needed to effectively prove an earlier occurrence of $M$. u. uniformis, so that the same new tool could be used for better correlation of the defined GSSP. In fact, even at the moment of definition of the Devonian GSSP, not only the first occurrence of $M$. u. uniformis but also other datum-levels of different fossil groups were indicated as tools for worldwide correlation, implying that each new tool available in the future would be welcome to increase the correlation potential of the defined boundary.

Within the following few years, all series and stages of the Silurian and Devonian systems were defined with a convenient GSSP. This was possible due to increasing cosmopolitan biotic conditions away from both sides of the Devonian boundary, and also because of the speeding effect prompted by the presence of the Silurian/Devonian Committee members within the adjoining ICS subcommissions.

\section{Present state}

The exponential increase of GSSP definition with time recorded for the Silurian and Devonian systems was not observed for other individual or groups of systems. Moreover, the impact of the definition of the Devonian boundary was minor on another major boundary discussion, the Pliocene/Pleistocene (or Neogene/Quaternary) boundary, that had already started more than 20 years earlier and had to last 12 more years before reaching a definition at the 27th IGC Moscow 1984 (Aguirre and Pasini, 1985; van Couvering, 1997).

It seems, therefore, that individual subcommissions take poor advantage of the experience already made by other subcommissions, or that they are not aware of what others have already done, or that conditions are objectively different from time (system) to time.

Historically, correlation tools and related numerical or relative geological time scales have conspicuously increased in the last four decades or so. After each new entry, groups of geologists have been tempted to abandon classical stratigraphic procedures in favour of a specialistic high-resolution x-type stratigraphy. So far, no effective, standard, complete, worldwide, deus-ex-machina solution, able to assure a common stratigraphic language from the past to the future, has yet appeared. However, the need has increased for a more integrated approach in the use of all possible correlation tools in chronostratigraphy. So, in spite of different tools practically available for different systems, the basic conditions and the best philosophy to improve the chronostratigraphy remain the same.

For these reasons, the slow rate of GSSP definition was identified as a concern by the 45th IUGS Executive Committee Meeting held in Florence, January 26-30, 1999. The ICS, in the person of its chairman, was asked to speed up its work on the matter of chronostratigraphic definitions. I was able to assure that this message was conveniently conveyed to the different ICS subcommissions, and especially to the two subcommissions involved in the XIV International Congress on the Carboniferous-Permian held in Calgary, August 17-21, 1999.

However, I felt the two different subcommissions are working in a very different way.

The Permian Subcommission is very well advanced on its task. It already settled the formal subdivision of the System into three series (Cisuralian, Guadalupian and Lopingian, as temporary nom- ina nuda) (Jin et al., 1996). Studies on individual component global standard stages are ongoing (Glenister et al., 1999) and should lead to a consensus on the selection of the related GSSPs in a special session of the 31st IGC Rio de Janeiro 2000.

The relatively similar difficulties of worldwide correlation deriving from the Permo-Carboniferous glaciation, successfully faced by the Permian Subcommission, make it difficult to understand the poor results so far obtained by the Carboniferous Subcommission. In fact, more than twenty years of modern activity, following a long lasting tradition of stratigraphic studies on the Carboniferous (Wagner and Winkler Prins, 1997) have led only to a twofold subdivision of the System and the definition of the related GSSP (Brenckle et al., 1997). Most of the time was spent in recurrent endless discussions (following each new rearrangement of the Subcommission membership) about the marked palaeobiogeographic provincialism, the relevance of terrestrial chronostratigraphic units and the difficulty of assuring satisfactory cross-correlations.

It seems that the aim at perfection has hampered the achievement of a minimum common level of chronostratigraphic nomenclature. Waiting for the best correlation to be discovered has resulted practically in no correlation potential.

Similar problems and hesitating approaches were encountered also in other systems (namely part of the Devonian, most of the Permian, part of the Neogene, the entire Quaternary), but they have been overcome.

I tried to convey this message during some meetings of the Carboniferous Subcommission, with no result. At the Calgary Congress, I was able to discuss the issue informally with some of the Subcommission members, trying to understand the reason for this lack of response.

I have got two basic impressions.

(1) Most of the members are excellent scientists, engaged in detailed stratigraphic correlation at different scales, working within the Subcommission as in a common research project on stratigraphic correlation. The aim of standard definition is felt as a distant one, poorly focused or more or less confused with correlation. Notably, the notion of a permanent physical boundary stratotype is neglected, as is the meaning of GSSP.

(2) Most members are not aware of the fact that the ICS subcommissions have precise aims, scope and terms of reference, which are condensed in the Guidelines (Cowie et al, 1986; Remane et al., 1996), as well as a common stratigraphic philosophy largely reflected in the two editions of the International Stratigraphic Guide (Hedberg, 1976; Salvador, 1994). As an example, such a philosophy was not followed by Heckel and Villa (1999).

I have to say that such attitudes have been observed to arise at least from time to time in most of the subcommissions.

If my impressions are true, I invite the geological community, especially the stratigraphers in the widest sense, to accept after careful consideration this frame of the ICS and to actively contribute to the standard definition of the chronostratigraphic units still undefined. This applies particularly to those who happen to be already members of subcommissions. On the other hand, IUGS and ICS should make sure that their financial support, although limited, is actually used for their institutional duties.

Modern international geology is based on the acceptance of stratigraphic principles and on fundamental stratigraphic rules expressed in common terminology and nomenclature (Vai, 1997). The sooner a set of complete, formally defined standard global chronostratigraphic units at the stage level is completed, the better the more advanced new Earth science disciplines will integrate with the traditional ones, thus allowing new perspectives to the challenges geology is facing.

A special co-operative scientific effort of the global geological community under the guidance of IUGS and ICS is needed to accomplish the formal definition of the entire chronostratigraphic scale within a reasonable time. This should be done within the next decade, as the time is ripe. 


\section{References}

Aguirre E. and Pasini G., 1985, The Pliocene-Pleistocene boundary: Episodes, v. 8, pp. 116-120.

Brenckle P.L., Baesemann J.P., Lane H.R., West R.R., Webster G.D., Langenheim R.L. Brand U. and Richards B.C, 1997, Arrow Canyon, the midCarboniferous boundary stratotype: Proceedings XIII International Congress on the Carboniferous and Permian, Cracow 1995, part 3, pp.149164.

Capellini J., (1882), Résolutions concernant la nomenclature et les couleurs: Congrès Geologique International 2me Session Bologne 1881, Compte rendu, Fava et Garagnani Bologna, pp. 196-198.

Cowie J.W., Ziegler W., Boucot A.J., Bassett M.B. and Remane J., 1986, Guidelines and statutes of the International Commission on Stratigraphy: Courier Forschungsinstut Senkenberg, v. 83, pp.1-14.

Erben H.K. (ed), 1962, Symposiums-Band, Internationale Arbeitstagung über die Silur/Devon-Grenze und die Stratigraphie von Silur and Devon, Bonn-Bruxelles 1960: Schweizerbart'sche Verlagb. Stuttgart, 315 pp.

Glenister B.F., Wardlaw B.R., Lambert L,L, Spinosa C., Bowring S.A., Erwin D.H., Menning M. and Wilde G.L., 1999, Proposal of Guadalupian and component Roadian, Wordian and Capitanian stages as international standards for the Middle Permian Series: Permophiles, no.34, pp.3-11.

Heckel P.H. and Villa E., 1999, Proposal toward consensus on further subdivision of the two Subsystems of the Carboniferous System: XIV ICCP, Calgary, Alberta, Canada, August 17-21, 1999, Programme with abstracts, p. 53.

Hedberg H. D. (ed), 1976, International Stratigraphic Guide: J. Wiley \& S. New York, $200 \mathrm{pp}$

Jin Yugan, Wardlaw B.R., Glenister B.F. and Kotlyar G.V., 1997, Permian chronostratigraphic subdivisions: Episodes, v. 20, 10-15.

King W.B.R., 1950, The Pliocene-Pleistocene boundary, Introduction: International Geological Congress 18th Session Great Britain 1948, London, part 9, p. 5.

Martinsson A. (ed), 1977, The Silurian-Devonian Boundary: IUGS s. A, no. 5, Schweizerbart'sche Verlagb. Stuttgart, 349 pp.

Oakley K.P. (ed), 1950, Proceedings of section H, The Pliocene-Pleistocene Boundary: International Geological Congress 18th Session Great Britain 1948, London, part 9, 132 pp.
Remane J., Bassett M.G., Cowie J.W., Gohrbandt K.H., Lane H.R., Michelsen O. and Wang N., 1996, Revised guidelines for the establishment of global chronostratigraphic standards by the International Commission on Stratigraphy (IUGS): Episodes, v. 19, pp. 77-81.

Salvador A. (ed), 1994, International Stratigraphic Guide, Second Edition: IUGS and Geological Society of America, Boulder, 214 pp.

Sorgenfrei T. (ed), 1964, Report of the Twenty-First Session Norden 1960 Part 28 General Proceedings IGC, Copenhagen, 375 pp.

Vai G.B., 1997, Twisting or stable Quaternary boundary? A perspective on the glacial late Pliocene concept: Quaternary International, v. 40, pp. 1122.

Van Couvering J.A. (ed), 1997, The Pleistocene Boundary and the Beginning of the Quaternary: Cambridge University Press, $296 \mathrm{pp}$

Wagner R.H. and Winkler Prins C.F., 1997, Carboniferous chronostratigraphy: Quo vadis?: Proceedings of the XIII International Congress on the Carboniferous and Permian, Cracow 1995, part 1, pp. 188-196.

Gian Battista Vai is Professor of Stratigraphic Geology at Department of Earth Sciences, University of Bologna. His research concentrates on Mediterranean Palaeozoic. He was member of the ICS Silurian/ Devonian Boundary Committee, Silurian and Devonian subcommissions, and is currently member of the Neogene and Quaternary subcommissions. He was member and Vice Chairman of the IGCP Board (19801986).

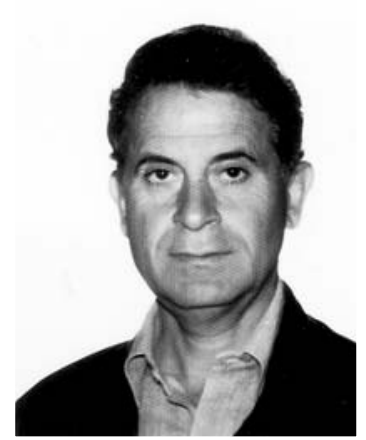

\title{
CALL FOR PAPERS
}

Episodes is the quarterly science and news journal of the International Union of Geological Sciences (IUGS). It focuses on the publication of results of scientific research and other information addressing issues of interest to the global earth-science community. Special emphasis is given to topics involving geological aspects of population growth and economic development and their resulting impacts on or implications for society. As the principal publication of the IUGS, Episodes also carries information about IUGS scientific programs and activities to the extent necessary to communicate effectively with the worldwide IUGS constituency.

Contributions of the following types of manuscripts are here solicited:

- scientific articles

- conference reports

- news and views

- letters to editor

- book reviews

- information on training courses (especially those geared to participants from developing countries)

- noteworthy new publications, including national or regional geologic maps

Episodes also invites photos or other images for the front cover. Photos must be of high technical quality and tell an interesting geological story. A color transparency and one color print (at least $9 \mathrm{~cm} \times 12.6 \mathrm{~cm}$ ) are required for submission, which should be supplemented with a short explanatory paragraph (no more than 100 words).

Please address all contributions to:

\author{
The Editor \\ Episodes \\ P. O. Box 823, 26 Baiwanzhuang Road \\ 100037 Beijing, CHINA \\ Tel: +86-10-68320827; \\ Fax: +86-10-68328928; \\ E-mail: episodes@public2.bta.net.cn
}

